\title{
Degradation Study of Available Brands of Metformin in Karachi Using UV Spectrophotometer
}

Safila Naveed*, Areesha Shafiq, Madiha Khan, Madiha Jamal, Hira Zafa , Hira Hashim and Lubna Urooj

Jinnah University for Women, Karachi, Pakistan

\begin{abstract}
There are several different brands available for metformin as it is the most prescribed oral antihyperglycemic agent that is used for Type-II Diabetes mellitus. The objective of this study develop the degradation studies of different brands of metformin HCL500 mg. Metformin was subjected to different stress conditions as per (ICH) International Conference on Harmonization guidelines. A UV spectroscopic method was developed for analysis of the drug in the presence of the degradation products. Methanol and distilled water were used as solvents. The amount of degraded drug was calculated by taking absorbance at $237 \mathrm{~nm}$. According to the assay limit of USP specified that the content should not be less than $95 \%$ and not more than $105 \%$ of labelled amount. Brand $\mathrm{A}$, $\mathrm{C}$ and $E$ are degraded after heating. Brand $A, B, C$, and $D$ are degraded by UV light exposure .On basic $p H$ brand $A$, and $\mathrm{C}$ showed degradation after the addition of $0.1 \mathrm{~N} \mathrm{NaOH}$ while other brands does not degraded as base has no impact on metformin concentration and the original $\mathrm{pH}$ of metformin $\mathrm{HCL}$ was 6.68 before addition of acid and base. On addition of $0.1 \mathrm{~N} \mathrm{HCL}$ all brands showed heavy degradation. After 15 days the time affects and degrades the metformin concentration of all brands. The method was found to be simple and less time consuming and cost effective. Hence this method can be successfully used to study stress degradation behavior of metformin in small industry where high end instruments are not available.
\end{abstract}

Keywords: Metformin HCL; Degradation studies; Assay; USP

\section{Introduction}

Currently the most commonly prescribed medications for Type 2 diabetes are metformin and the second generation sulfonylureas which include gliclazide, glibenclamide and glimperide. For many patients with Type II diabetes, monotherapy with an oral antidiabetic agent is not sufficient [1]. Metformin Hydrochloride ( $\mathrm{HCl})$ Tablets, USP is an oral antihyperglycemic drug used in the management of type 2 diabetes. Metformin $\mathrm{HCl}$, USP is not chemically or pharmacologically related to any other classes of oral antihyperglycemic agents. The structural formula is as shown in Figure $1[2,3]$.

Spectrophotometry technique is generally preferred especially by small-scale industries as the cost of the equipment is less and the maintenance problems are cheap. The method of analysis is based on the measuring absorption of a monochromatic light by colorless compounds in the near (UV) ultraviolet path of spectrum (200$380 \mathrm{~nm}$ ). UV spectrophotometry can be used for stress-degradation studies of metformin. The active pharmaceutical ingredient is subjected to a number of forced degradation conditions to include acidic, basic and photo conditions as per ICH guidelines [4].

Forced degradation should be one of the activities performed early in the development process to ensure that the method is discriminating before a lot of time, effort, and money have been expended. It is important to determine the conditions responsible to degrade the drug. Earlier publications have reported high-performance liquid chromatography (HPLC) methods for metformin [5-7] but no method by $\mathrm{U}-\mathrm{V}$ as degradation studies available in the literature.

\section{Parameters in Forced Degradation}

The typical forced degradation studies on drug substance include Temperature and or with humidity, Acid/base Stress testing, Time, Photodegradation and $\mathrm{pH}$ variation (high and low).

\section{Acid/base stress testing}

Acid/Base stress testing is performed to force the degradation of a drug substance to its primary degradation products by exposure to acidic or basic conditions over time. The functional groups likely to introduce acid/base hydrolysis are compounds that have labile carbonyl functionality such as amides (lactams), esters (lactones), carbamates, imides, imines, alcohols and aryl amines [4].

\section{Thermal/Thermal/humidity stress testing}

Thermal or thermal/humidity stress testing is performed to force the degradation of a drug substance to its primary degradation products by exposure to thermal/humidity conditions over time [4].<smiles>CN(C)C(=N)NC(=N)N</smiles>

Figure 1: Structure of metformin.

*Corresponding author: Safila Naveed, Jinnah University for Women, Karachi, Pakistan, Tel: 36632471; E-mail: safila117@yahoo.com

Received December 24, 2013; Accepted January 23, 2014; Published January 29, 2014

Citation: Naveed S, Shafiq A, Khan M, Jamal M, Zafar H, et al. (2014) Degradation Study of Available Brands of Metformin in Karachi Using UV Spectrophotometer. J Diabetes Metab 5: 328. doi:10.4172/2155-6156.1000328

Copyright: $\odot 2014$ Naveed S, et al. This is an open-access article distributed under the terms of the Creative Commons Attribution License, which permits unrestricted use, distribution, and reproduction in any medium, provided the original author and source are credited. 
Citation: Naveed S, Shafiq A, Khan M, Jamal M, Zafar H, et al. (2014) Degradation Study of Available Brands of Metformin in Karachi Using UV Spectrophotometer. J Diabetes Metab 5: 328. doi:10.4172/2155-6156.1000328

Page 2 of 3

\section{Degradation by UV light}

Many natural and synthetic polymers are attacked by UV ultraviolet radiation and products made using these materials may crack or disintegrate (if they're not UV-stable). The problem is known as UV degradation, and is a common problem in products exposed to sunlight and continuous exposure is a more serious problem than intermittent exposure since attack is dependent on the extent and degree of exposure.

\section{Experimental}

\section{Metformin}

The Metformin Hcl brands used were Neophage $500 \mathrm{mg}$, Glucophage $500 \mathrm{mg}$, Metaphage $500 \mathrm{mg}$, Biguanil $500 \mathrm{mg}$, Neodipar of Abbott laboratories (Pakistan) Ltd, Merck (Private) Ltd., Efroze Chemical Ind. (Private) Ltd. Popular Chemical works (Pvt.) Ltd.,SanofiAventis (Pakistan) Ltd. respectively.

\section{Reagents}

All the reagents used were of analytical grade including hydrochloric acid, sodium hydroxide, Deionized water used was double distilled, deionized and filtered.

\section{Glasswares}

Volumetric flask, pipette, beakers, measuring cylinder, funnel, stirrer all the glassware's were of Pyrex type and were washed with chromic acid followed by thorough washing with water and finally rinsed with double distilled or de-ionized water which was freshly prepared in the laboratory.

\section{Equipments used}

$\mathrm{pH}$ meter: Starter2000 OHAUS, Spectromter: T80 uv/vis spectrometer PG Instrument, Weighing Balance: Item PA214C (Pioneer OHAIUS),Water Bath: Digital constant temperature tank HH-4, UV Lamp: Serial N 045571, LF-204.LS,4W-365 nm, 4W-254 nm, Power: 8N, Friabilator: Curio: FB-1004, Hardness Tester: Monsanto Hardness Tester, and Vernier Caliper.

\section{Preparation of 0.1 M hydrochloric acid}

$9.1 \mathrm{ml}$ hydrochloric acid of analytical grade $(36 \%, 11 \mathrm{~N})$ was taken in a liter volumetric flask and the volume was made up to the mark with de-ionized water.

\section{Preparation of $0.1 \mathrm{~N}$ sodium hydroxide}

$40 \mathrm{gm} \mathrm{NaOH}$ was dissolve in small quantity of water taken in a liter volumetric flask and the volume was made up to the mark with de-ionized water.

\section{Preparation of Metformin solution}

Weigh and finally crushed tablets and weigh crushed tablets accurately for making primary solutions of metformin, Neodipar (0.0318 gm), Glucophage (0.1064), Neophage (0.1056) were weighed accurately and introduced in $100 \mathrm{ml}$ volumetric flasks. Add $70 \mathrm{ml}$ of water and shake virgously for $15 \mathrm{~min}$ makeup the volume, filter and discard first $20 \mathrm{ml}$ of filtrate. Dilute $10 \mathrm{ml}$ to $100 \mathrm{ml}$ with water again dilute $10 \mathrm{ml}$ of resulting solution to $100 \mathrm{ml}$ with water. Determine the absorbance at max of $232 \mathrm{~nm}$.

\section{Procedure for Degradation Studies}

\section{For heat}

Place the primary solution in the water bath at $90^{\circ} \mathrm{C}$ for $30 \mathrm{~min}$ and measure the absorbance at the same wavelength $(237 \mathrm{~nm})$.

\section{For UV light}

Take the solution from the primary solution and place it in U-V light for $30 \mathrm{~min}$ and measure the absorbance at the same wavelength (237).

\section{For time}

We placed the primary solution for 15 days and measure the absorbance after 15 days at the same wavelength.

\section{For acidic pH}

Place the final solution of metformin in a beaker and add $0.1 \mathrm{~N}$ HCL drop wise to the final solution and keep adding $0.1 \mathrm{~N}$ HCL until the $\mathrm{pH}$ reaches to 3 . Then determine the absorbance at $232 \mathrm{~nm}$.

\section{For basic pH}

Place the final solution of metformin in a beaker and add $0.1 \mathrm{~N}$ $\mathrm{NaOH}$ until the $\mathrm{pH}$ reaches to 9.5. Determine the absorbance of this solution at maximum of $237 \mathrm{~nm}$.

\section{Results and Discussion}

\section{Degradation studies}

The limit of assay by USP specified that the content should not be less than $95 \%$ and not more than $105 \%$ of labelled amount. All brands of metformin results are out of stated limit for assay before any degradation. Brand A, C and $\mathrm{E}$ are degraded after heating. Brand A,B,C and $\mathrm{D}$ are degraded by UV light exposure. All brands of metformin $\mathrm{A}, \mathrm{B}, \mathrm{C}, \mathrm{D}$, and $\mathrm{E}$ degraded after the addition of $0.1 \mathrm{~N}$ HCL into it showing that acid has the most degradation impact on the product. Only brand $\mathrm{A}$, and $\mathrm{C}$ showed degradation after the addition of $0.1 \mathrm{~N}$ $\mathrm{NaOH}$ while other brands does not degraded as base has no impact on metformin concentration and the original $\mathrm{pH}$ of metformin HCL was 6.68 before addition of acid and base. All brands of metformin show degradation after 15 days that was the effect of time on metformin HCL concentration (Table 1 and Figure 2).

\section{Conclusion}

It was used to study the stress-degradation studies as per ICH guidelines. Metformin was found to be degraded in all types of stress

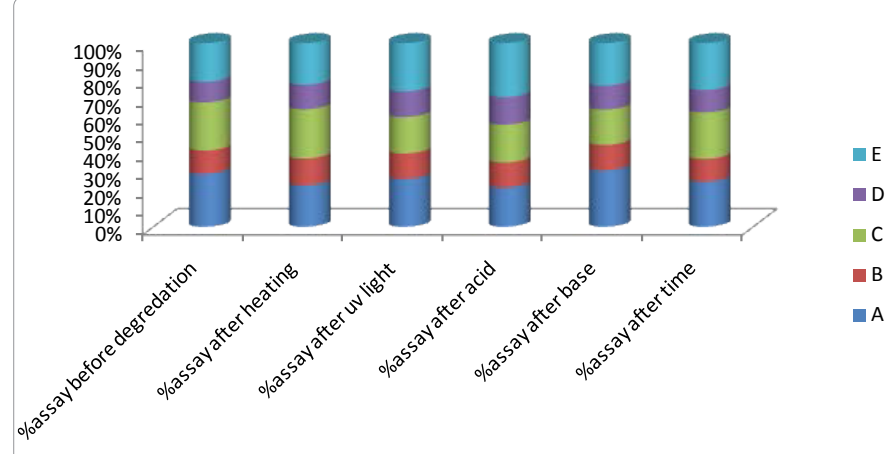

Figure 2: \% Availability before and after degradation. 
Citation: Naveed S, Shafiq A, Khan M, Jamal M, Zafar H, et al. (2014) Degradation Study of Available Brands of Metformin in Karachi Using UV Spectrophotometer. J Diabetes Metab 5: 328. doi:10.4172/2155-6156.1000328

Page 3 of 3

\begin{tabular}{|c|c|c|c|c|c|c|}
\hline Brand s & $\%$ assay before degredation & $\%$ assay after heating & $\%$ assay after uv light & $\%$ assay after acid & $\%$ assay after base & $\%$ assay after time \\
\hline A & $175.96 \%$ & $126.65 \%$ & $128.10 \%$ & $77.85 \%$ & $171.36 \%$ & $106.58 \%$ \\
\hline B & $76.80 \%$ & $81.71 \%$ & $68.23 \%$ & $49.79 \%$ & $77.11 \%$ & $53.50 \%$ \\
\hline $\mathrm{C}$ & $159.40 \%$ & $150.02 \%$ & $97.64 \%$ & $74.77 \%$ & $107.28 \%$ & $109.23 \%$ \\
\hline $\mathrm{D}$ & $68.51 \%$ & $74.97 \%$ & $68.41 \%$ & $54.76 \%$ & $72.82 \%$ & $52.92 \%$ \\
\hline$E$ & $128 \%$ & $126.97 \%$ & $129.13 \%$ & $106.87 \%$ & $128.72 \%$ & $110.46 \%$ \\
\hline
\end{tabular}

Table 1: \% Availability of different brands of metformin before and after degradation.

conditions and was found to be less stable. The proposed method is accurate and precise as well as reproducible and economical and can be successfully used degradation studies of different dosage form. It was concluded that only brand "A" showed accepted results among other brands for all the stresses applied for degradation studies.

\section{References}

1. Marathe PH, Arnold ME, Meeker J, Greene DS, Barbhaiya RH (2000) Pharmacokinetics and bioavailability of a metformin/glyburide tablet administered alone and with food. J Clin Pharmacol 40: 1494-1502.

2. The Indian Pharmacopoeia (1996) (4thedn) New Delhi: The controller of publications: 469.

3. Budavari S (2001) The Merck index (13thedn), Whitehouse Station Merck \& Co. Inc: 998
4. Food and Drug Administration, HHS (2003) International Conference on Harmonisation; Stability Data Package for Registration Applications in Climatic Zones III and IV; Stability Testing of New Drug Substances and Products availability. Notice. Fed Regist 68: 65717-65718.

5. Safila Naveed, Sultana N, Arayne MS (2011) Simultaneous Quantitation of Enalapril, Metformin, Glibenclamide and Glimepride In Bulk Material Pharmaceutical Formulations and Human Serum Using RP-HPLC. Internationa Journal Pharma Research Development 3: 24

6. Sultana N, Naveed S, Arayne MS (2013) Monitoring of In Vitro Interaction Studies of Enalapril with Hypoglycemic Agents by LC-UV. Research and Reports in Medicinal Chemistry 3: 1-7.

7. Sultana N, Naveed S, Arayne MS (2013) Development and Validation of a Simple and Efficient RPLC Method for Analysis of Captopril, Metformin, Pioglitazone and Glibenclamide in API, Formulations and Human Serum. Pharm Anal Acta 4: 257 